\title{
Greatness in HCT and greatness in wine
}

\section{Shaun McCann ${ }^{1}$}

Published online: 28 January 2020

c) Springer Nature Limited 2020
In William Shakespeare's Twelfth Night, Malvolio says; 'Some are born great, some achieve greatness, and some have greatness thrust upon them'.

There have been 'great moments' in haematopoietic cell transplantation (HCT) and similar moments in wine making. However, it is with great trepidation that I mention great people or events, in either, as one is bound to offend somebody, somewhere. But here goes!

How do we define greatness (Fig. 1)? Some say it is a concept of a state of superiority affecting an object. But who decides? Franz Ernst Christian Neumann (1834-1918) a German pathologist, and little known, who studied under Virchow, can be credited with early observations on cell biology which provided haematologists with an understanding of the importance of bone marrow [1]. Yet he is not recognised as 'great', in haematological terms, perhaps because his ideas were ridiculed by his 'boss' Virchow and by Ehrlich and Hayem. 'The beginning of Stem Cell research can be dated back to Ernst Neumann, who was appointed professor of pathology at Konigsberg in 1866 and described in a preliminary communication the presence of nucleated red blood cells in bone marrow (BM) saps. He concluded in his subsequent papers, that during postembryonic life, erythropoiesis and leukopoiesis are taking place in the BM. On the basis of his observation, Ernst Neumann was the first to postulate the BM as blood forming organ with a common SC for all hematopoietic cells' according to Zech et al. (Fig. 2).

A number of 'histories' of HCT have been written [2-5]. Undoubtedly the 'Trinity Project' in Los Alamos was a significant event in the development of the idea of HCT. There are many 'great'names associated with HCT but I suppose Georges Mathé and E Donnall Thomas are the most widely

Shaun McCann

shaunrmccann@gmail.com

1 University of Dublin Trinity College, Haematology Emeritus, Dublin, Ireland known to clinicians. Some believe that Mathé should have shared the Nobel Prize with Thomas. As we know there are many clinicians and researchers associated with HCT [3] but the unravelling of the HLA system initially by Murray (who shared the Nobel Prize with Thomas), van Rood and others paved the way for selecting the most appropriate donors.

One of the 'great' inventions in HCT was the Hickman Catheter invented in the 1970 s by Bob Hickman, a paediatric nephrologist. This may seem insignificant but the benefits of his invention were 'great'. As Fred Applebaum said 'the Hickman catheter was a gift to the world'. 'People make contributions in lots of ways; some have deep scientific insights that uncover DNA or how viruses work. Bob's contribution, from a scientific standpoint, was relatively simple. But his invention saved more suffering, anxiety, and pain than almost anyone I can imagine' [6].

There are great grapes and great wine makers and when the two come together great wine is made. But again, who decides? There are many factors influencing the final product; the grape variety (Chardonnay is the most widely planted grape in the world), the age of the vines, the soil in which the vine is planted, the aspect, fashion, politics and transport methods [7], weather and disease. Soil drainage is also important and roots which struggle to find water produce excellent grapes for wine. Some grapes, such as Cabernet, like sandy soil whereas other vines prefer stony soil. Twenty years ago, oenologists who manipulated grape varieties and methods of fermentation were in demand, whereas today minimal intervention is favoured. The trend towards 'organic' wines and bio-dynamic farming is growing apace. A combination of balance, taste and longevity are all contributing factors although fashion also plays a role and should not be underestimated. Like 'great' art, wine styles come and go. The paintings of El Greco (1541-1614) and Caravaggio (1571-1610) which are lionised today, languished in obscurity until the 20th century. The Romans favoured sweet white wines, whereas today dry white and red wines are in demand. In the 1980s, oaky Chardonnays were widely consumed, whereas today unoaked Chardonnay has pride of place. Some people favour a numerical scoring system 


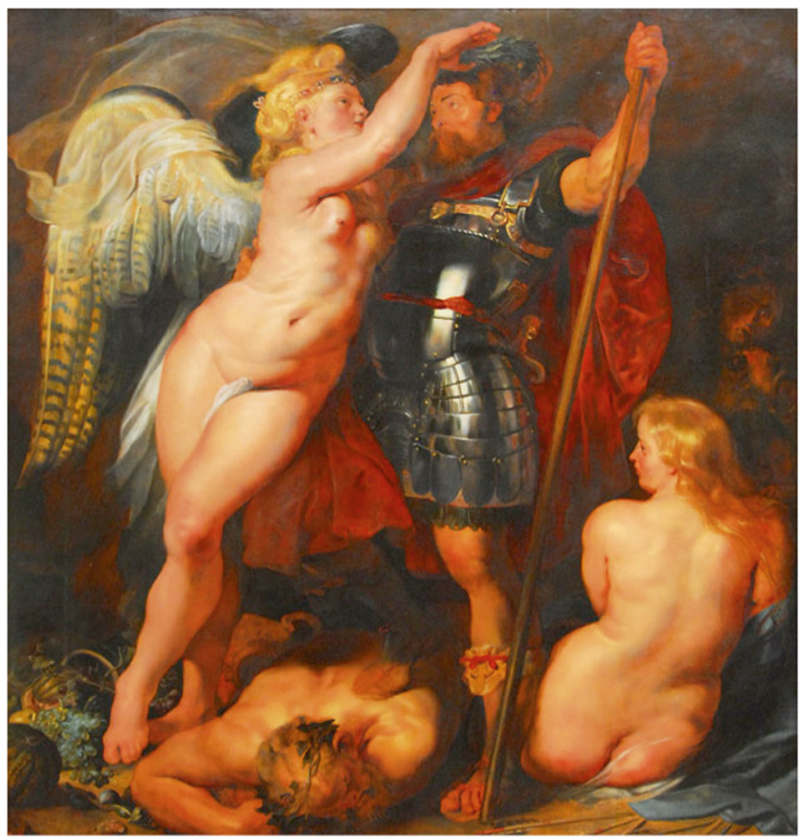

Fig. 1 Crowning of the Hero by Peter Paul Rubens (1577-1640).

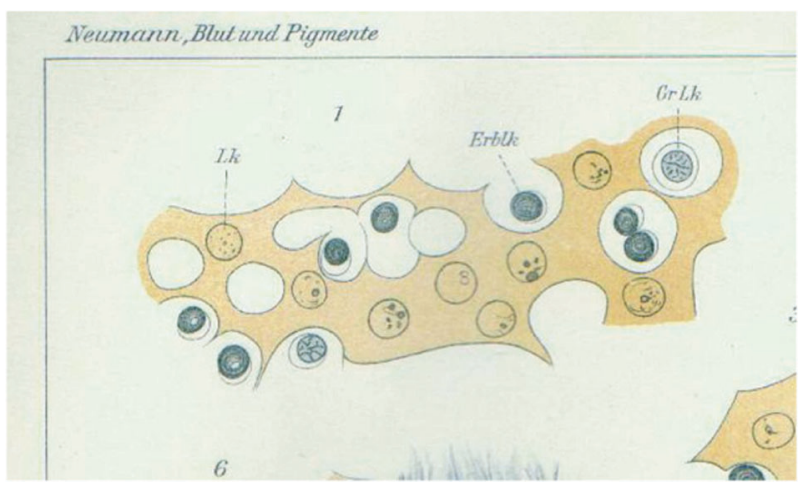

Fig. 2 '...the Great-Lymphocyt' as a stem cell for the postembryonic and embryonic development of erythropoiesis and leukopoiesis in the bone marrow and the embryonic liver (as shown here).

made famous by Robert Parker, but others decry this and call it subjective, unreliable and unreproducible. Therefore, trying to pinpoint great wines or developments in wine making are fraught.

Looking at wines from Bordeaux I suppose Château Pétrus, a top-quality wine from Pomerol, made exclusively from Merlot grapes, is still considered one of the great wines of the world. It came to prominence in 1945 and received its American reputation in the mid-1960s. The Château is not very impressive, as a building. For botrytised Semillon Château d'Yqem is still pre-imminent [8].

The red wines of Burgundy continue to represent 'something special' to wine drinkers. Wines from Clos de Vougeot and Romanée-Conti have great reputations but there are many lesser wines well worth drinking. The top wines from Burgundy are extremely expensive and out of the price range of ordinary mortals (you might taste one if you have a friend who is a gynaecologist, orthopaedic surgeon or an oncologist). White wines from Burgundy vary from the great wines of Puligny-Montrachet, including Mersault, many of which are capable of long ageing, to wines from the Mâconnais, including Pouilly-Fuissé which are not expensive and best consumed when young. What may be surprising to some is that many pundits think the 'great' white wines benefit form decanting before drinking.

Of course, wine quality is, like many things, subject to prejudice. Red and white wines from Bordeaux and Burgundy took a severe hammering after Steven Spurrier's comparison, in a blind tasting, between wines from California and France [9]. Château Montelena and Stag's Leap from Napa were victorious much to the chagrin of the French. There are many great wine makers in Napa, Sonoma and other parts of the United States, although tastes have changed recently and there is a move away from heavy fruity Cabernets to more 'refined' wines.

We are all indebted to Dom Pérignon and his contemporaries for developing 'great' Champagne which was particularly fashionable in St Petersburg in the $19^{\text {th }}$ century. Made from Chardonnay with Pinot Noir and Pinot Meuniere with secondary fermentation in the bottle, it continues to delight although I believe that the sparkling wines from Franciacorta in Lombardy offer much better value. Surprisingly, to some, sparkling wines from England are beginning to oust Champagne.

Although there are numerous very good wine makers in Australia and New Zealand, I suppose Penfolds in South Australia (founded by an English physician) continues to retain poll position.

Can individuals or families make a difference? There is no doubt that the Ricasoli and Antinori families have made huge contributions to the resurgence of Italian wine. Sassicia (Cabernet) and Tignanello (Sangiovese) continue to be the best sellers and great wines. Angelo Gaja in Piedmont and Franco Biondi-Santi (Fig. 3) have also made huge contributions.

In Spain the Tempranillo usually blended with Garnacha makes great and long-lived Riojas. Of course, there are excellent wines from Navarre, Ribera del Duero and the oxidised wines from Jerez (Sherry) and Manzanilla are world famous. The sweet botrytised wines from Hungary (Tokaji) are widely praised and there are many outstanding wines from Greece, Turkey, India, China, South America (Argentina and Chile) and South Africa.

This list is not exhaustive but merely points out some of the 'great wines' and grape growing areas. Going back to our opening quote there will be many 'great' names and 'great' moments in HCT and wine making in the future, but the use of the term 'great' is problematical. 


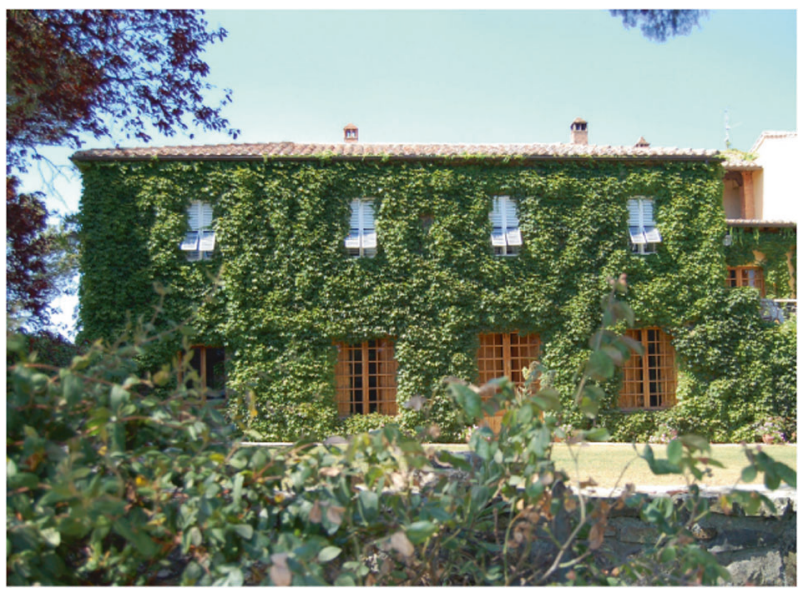

Fig. 3 Il Greppo, Franco Biondi-Santi's house near Montalcino. (photograph by Shaun McCann).

\section{Compliance with ethical standards}

Conflict of interest The author declares that he has no conflict of interest.

Publisher's note Springer Nature remains neutral with regard to jurisdictional claims in published maps and institutional affiliations.

\section{References}

1. Zech NH, Shkumatov A, Koestenbauer S. The magic behind stem cells. J Assist Reprod Genet. 2007;24:208-14.

2. Storb R. HSCT: historical perspective. In: Carreras E, Dufour C, Mohty M, Kröger N, editors. EBMT handbook. Switzerland: Springer Open; 2019. Fondation José Carreras, Contre La Lucémie.

3. Gale RP, McCann S. A brief history of hematopoietic cell transplantation in hematopoietic cell transplants: concepts, controversies, and future directions. In: Lazarus HM, Gale RP, Keating A, Bacigalupo A, Munker R, Atkinson K, Abutalib SA, editors. Hematopoietic Cell Transplants. UK: Cambridge University Press; 2017.

4. Gratwohl A, Mohty M, Apperley J. The EBMT: history, present, and furure. In: Carreras E, Dufour C, Mohty M, Kröger N, editors. EBMT handbook. Switzerland: Springer Open; 2019. Fondation José Carreras, Contre La Lucémie.

5. Santos GW. History of bone marrow transplantation. Clin Haematol. 1983;12:611-39.

6. ASCOPost Staff. Robert O. Hickman MD, dies at 92. ASCOPost may 10th. 2019.

7. Robinson J, Harding J, The Oxford companion to wine. 4th ed. Oxford: Oxford University Press; 2015.

8. McCann SR. The good, the bad and the ugly. Bone Marrow Transpl. 2018. https://doi.org/10.1038/s41409-018-0-0237-y.

9. McCann SR. The judgement of Paris. Bone Marrow Transpl. 2018. https://doi.org/10.1038/s41409-018-0336-9. 